\title{
PENDEKATAN EKONOMI SYARIAH DALAM MENYELESAIKAN MASALAH EKONOMI AKIBAT PANDEMI COVID-19
}

\author{
Nurhidayat \\ Universitas Muhammadiyah Jakarta \\ Email: n.sag@umj.ac.id
}

\begin{abstract}
Every disaster caused by a variety of natural factors such as earthquakes, floods, eruptions and disease outbreaks, always have an impact on the emergence of various economic problems. Scarcity of goods, inflation and the emergence of bad behavior of hoarding goods. These three economic problems always arise, and become a complicated problem in the economic system. The emergence of the corona virus that has swept parts of the world and Indonesia has raised these three economic problems. This study aims to provide an overview and analyze how sharia economic approaches in answering economic problems due to the co-19 pandemic. Through this Islamic economic approach, can the three economic problems be overcome. The main problem answered in this study is whether the Islamic economic approach is able to provide solutions to economic problems due to co-19. How is the Islamic economic solution in responding to economic problems as a result of co-19. This study concludes that conceptual sharia economics is indeed a solution to economic problems due to co-19. Because the sharia economics approach is conceptualized and has an orientation as a problem solving of various economic problems that can arise at any time and in any world.
\end{abstract}

Keywords: Sharia Economics, Economics, Covid-19Leadership

\begin{abstract}
Abstrak
Setiap bencana yang diakibatkan oleh berbagai faktor alamiah gempa bumi, banjir, erupsi dan wabah penyakit, selalu berdampak terhadap munculnya berbagai persoalan ekonomi. Kelangkaan barang, inflasi dan munculnya perilaku buruk penimbunan barang. Tiga persoalan ekonomi ini selalu muncul, dan menjadi persoalan pelik dalam sistem ekonomi. Munculnya virus corona yang melanda sebagian dunia dan Indonesia telah memunculkan tiga persoalan ekonomi tersebut. Penelitian ini bertujuan untuk memberikan gambaran dan menganalisis bagaimana pendekatan ekonomi syariah dalam menjawab persoalan ekonomi akibat pandemi covid-19. Melalui pendekatan ekonomi syariah ini apakah ketiga persoalan ekonomi dapat teratasi. Adapun pokok persoalan yang dijawab dalam penelitian ini adalah apakah pendekatan ekonomi syariah mampu memberikan solusi terhadap persoalan ekonomi akibat covid-19. Bagaimana solusi ekonomi syariah dalam menjawab persoalan ekonomi sebagai dampak dari covid-19. Penelitian ini berkesimpulan bahwa ekonomi syariah secara konseptual memang menjadi solusi terhadap persoalan ekonomi akibat covid-19. Sebab pendekatan ekonomi syariah dikonseptualisasikan dan memiliki orientasi sebagai problem solving dari berbagai persoalan ekonomi yang bisa muncul kapan saja dan di dunia manapun.
\end{abstract}

Kata kunci: ekonomi syariah, ekonomi, covid-19.

P-ISSN : 2460-9595

E-ISSN : 2686-5149

DOI. 10.36908/isbank 


\section{Nurhidayat, PENDEKATAN EKONOMI SYARIAH DALAM MENYELESAIKAN MASALAH.}

\section{Dasar Pemikiran}

Sejak bulan Januari tahun 2020, hampir seluruh dunia termasuk Indonesia diguncang wabah virus corona, virus tersebut pertama kali muncul di Kota Wuhan China. Dampak yang ditimbulkan dari virus corona bersifat multidimensional (sosial, ekonomi, pendidikan, kesehatan dan politik). Berbagai kebijakan diberlakukan untuk mencegah penyebaran, antara lain social distancing dan physical distancing. Sehingga kebijakan tersebut ini berdampak kepada semua aktifitas termasuk bisnis. Akibatnya terjadinya penurunan aktifitas, para pedagang kecil berhenti berdagang sehingga mereka tidak memiliki income.

Penyebaran virus corona luar biasa dampaknya dalam kehidupan ekonomi sehingga kalau ini tidak dapat diatasi akan berdampak terhadap meningkatnya jumlah kemisikinan. Ekonom World Bank Vivi Alatas mengemukakan hal tersebut berdasarkan perhitungan data ekonomi. Bahkan menurutnya masyarakat miskin ini menjadi salah satu kategori yang paling rentan terdampak virus corona. Apalagi jika pemerintah melakukan kebijakan lockdown dampak terhadap peningkatan kemiskinan akan semakin signifikan, kenapa hal itu bisa terjadi karena masyarakat tidak memiliki akses untuk beraktifitas ekonomi akibatnya mereka tidak memiliki income. Jika hal ini terjadi dampak sosialnya akan semakin besar (Nurhidayat, carapandang.com, 29 March 2020).

Data dari BPS tahun 2019 menyebutkan terdapat 24,7 juta penduduk miskin di Indonesia. Jika persoalan virus corona ini tidak mampu diselesaikan maka pada tahun 2020 ini angka kemiskinan tersebut tidak mustahil akan mengalami peningkatan. Hal ini diakibatkan oleh kekuatan ekonomi yang semakin melemah mengakibatkan peningkatan kemiskinan. Menurut Direktur Riset Centre of Reform on Economy (Core) Pieter Abdullah virus corona yang tidak kunjung reda akan berdampak kepada kenaikan angka kemiskinan di Indonesia. Imbasnya adalah angka kemiskinan Indonesia diperkirakan meningkat (Data BPS tahun 2020, BPS.go.id, diakses 20 April 2020).

Data dari harian Republika terkait dengan virus corona tersebut ternyata berdampak negatif kepada peningkatan harga barang selain karena kelangkaan barang juga diakibatkan oleh biaya transportasi yang meningkat, selain itu daya beli masyarakat mengalami penurunan, dampak dari ini perdagangan mengalami penurunan. Sektor 
pariwisata yang paling terkena imbasnya, kebijakan social distancing dan penutupan beberapa maskapai penerbangan yang dibuat pemerintah mengakibatkan orang enggan untuk melakukan bepergian. Hal tersebut berdampak kepada sepinya tempat-tempat pariwisata. Kondisi ini yang merasakan akibatnya adalah kelompok menengah ke bawah. Data BPS NTB menyebutkan karena pariwisata merupakan salah satu sumber pendapatan NTB, maka hal ini sangat berdampak kepada kalangan masyarakat bawah (Republika.co.id., Selasa 14 Apr 2020).

Dampak lain dari penyebaran virus corona ini adalah adanya kemungkinan gelombang PHK secara signifikan yang diakibatkan melemahnya kondisi ekonomi. Laporan hasil kajian INDEF menyimpulkan bahwa virus corona dapat mengakibatkan PHK, hal ini disebabkan menurunnya angka pertumbuhan ekonomin 4-4,5 persen. Data dari Organisasi Buruh Internasional (International Labour Organizations/ILO) memperkirakan virus corona, akan menghilangkan 24,7 juta pekerjaan di dunia. Skenario rendahnya sebesar 5,3 juta. Adapun skenario pertengahannya sebanyak 13 juta pekerjaan. Dari total jumlah itu, 7,4 juta berada di negara-negara berpenghasilan tinggi (Republika.co.id, Senin 02 Mar 2020).

Departemen Tenaga Kerja Amerika Serikatnya menyebut, pengangguran meningkat lebih buruk dari yang diperkirakan 70.000 menjadi 281.000 selama pekan yang berakhir 14 Maret 2020. Sementara di Cina, sebanyak 5 juta warganya kehilangan pekerjaan pada periode Januari hingga Februari 2020. Rilis Biro Statistik China menunjukkan angka pengangguran naik 6,2\% per-Februari 2020 dari sebelumnya 5,3\% di Januari 2020. Sebagian pihak bahkan memperkirakan angka ini seharusnya lebih tinggi (Republika.co.id, Rabu 11 Desember 2019).

Wabah virus corona memberikan dampak signifikan terhadap perekonomian global khususnya di kawasan Asia. Tidak dapat dipungkiri, bahwa Indonesia juga tidak lepas dari efek wabah yang telah banyak menyebabkan kematian. Hal ini jelas akan menyebabkan nilai perekonomian semakin turun. S \& P Global memberikan sebuah laporan bahwa covid-19 ini dapat menimbulkan kerugian pada perekonomian Asia sebesar US\$ 211 miliar atau sama dengan lebih dari seperlima output perekonomian Indonesia dalam satu tahun. Kondisi global tersebut tentu akan berdampak kepada 


\section{0 | Nurhidayat, PENDEKATAN EKONOMI SYARIAH DALAM MENYELESAIKAN MASALAH................}

kondisi Indonesia, kalau dibiarkan bisa mengalami krisis ekonomi seperti tahun 1998 yang diakibatkan oleh krisis moneter (Republika.co.id, Senin 18 May 2020).

Beberapa faktor penting yang membuat Indonesia bisa mengalami krisis ekonomi adalah bila mayoritas pelaku ekonomi di hampir semua sektor tidak lagi dapat melakukan aktivitas perekonomian secara efektif. Kondisi ini akan menyebabkan tingkat pengangguran semakin tinggi, sehingga kondisi kemiskinan akan dapat mudah kita jamah. Indonesia rentang masuk ke dalam kondisi krisis ekonomi. Sebab pertumbuhan ekonomi mengalami perlambatan yang cukup tajam. Menurut Institute for Development of Economics and Finance (INDEF), perlambatan tersebut diperkirakan hanya 4,5-4,8 persen di tahun 2020 .

Negara Indonesia juga makin rentan mengalami kepanikan pasar keuangan global. Asian Development Bank (ADB) memberikan informasi bahwa sebanyak 38,5 persen surat utang pemerintah Indonesia digenggam oleh investor asing. Lebih tinggi dari negara Asia lainnya. Hal ini apabila terjadi aksi jual secara kolektif tentunya ini beresiko tinggi terhadap krisis ekonomi.

Indonesia merupakan salah satu negara yang memberlakukan larangan perjalanan ke China dalam rangka mengurangi penyebaran virus Corona. Seperti yang kita ketahui, bahwa virus berbahaya ini muncul pertama kali di China. Hal ini yang juga menjadi faktor menurunnya nilai ekonomi di Indonesia. Sebab China adalah negara eksportir terbesar di dunia. Indonesia sering melakukan aktivitas impor dari China dan China merupakan salah satu mitra dagang terbesar Indonesia. Apabila negara China mengalami penurunan produksi barang, maka global supply chain akan terganggu dan hal ini dapat mengganggu proses produksi yang membutuhkan bahan baku dari China. Jelas, dengan adanya virus Corona yang terjadi di China menyebabkan perdagangan China memburuk. Hal tersebut berpengaruh pada perdagangan dunia termasuk di Indonesia.

Masalah-masalah itulah yang muncul diakibatkan oleh pandemi covid-19 yang melanda dunia saat ini. Ekonomi syariah sebagai sebuah konsep sekaligus sistem ekonomi yang saat ini diakui oleh dunia. Maka pertanyaan yang muncul adalah 
bagaimanakah ekonomi syariah menjadi solusi terhadap persoalan-persoalan ekonomi tersebut.

\section{Tijauan Teori Ekonomi Syariah}

Menurut M. Nejatullah Siddiqi ekonomi syariah sebagai ilmu pemikiran muslim yang bertujuan untuk menjawab berbagai tantangan ekonomi manusia sesuai dengan zamannya, dengan berdasarkan kepada panduan dari Allah dan Rasul-Nya yang termaktub di dalam al-Qur'an dan Al-Sunnah, yang dibantu dengan akal dan pengalaman untuk memahaminya (Naqvi, 1985).

Syed Nawab Al Haider Naqvi menegaskan ekonomi syariah merupakan representasi perilaku kaum muslimin dalam suatu masyarakat muslim. Perilaku ekonomi tersebut seseuai dengan al-Qur'an dan Sunnah Rasul. Ekonomi syariah adalah perilaku Muslim yang representatif dalam masyarakat Muslim yang khas" Definisi yang populer dari ilmu ekonomi syariah adalah studi mengenai alokasi sumber daya yang langka yang mempunyai berbagai alternatif pemanfaatannya (Manan. 1984).

Dawam Rahardjo (1999) mengartikan ekonomi syariah ke dalam tiga makna. Pertama, ekonomi syariah sebagai ilmu ekonomi yang berlandaskan kepada nilai-nilai ajaran Islam. Kedua, ekonomi syariah sebagai sistem yang menyangkut pengaturan kegiatan ekonomi dalam suatu masyarakat atau negara berdasarkan suatu cara atau metode tertentu. Ketiga, ekonomi syariah sebagai kegiatan perekonomian umat Islam. Ketiga makna tersebut merupakan tiga pilar yang harus membentuk sebuah sinergi. Karena menurut Dawam Raharjo menekanan ekonomi syariah sebagai konsep dan sistem ekonomi.

S.M. Hasanuzzaman, mengartikan ilmu ekonomi syariah sebagai sebuah pengetahuan dan aplikasi dari ajaran /aturan Syariah yang mencegah ketidakadilan dalam memperoleh sumber-sumber daya material sehingga tercipta kepuasan manusia dan memeungkinkan mereka menjalankan perintah Allah (Siddiqi, 1981). 


\section{2 | Nurhidayat, PENDEKATAN EKONOMI SYARIAH DALAM MENYELESAIKAN MASALAH.}

Sri Edi Swasono, mengartikan ekonomi syariah sebagai sistem ekonomi yang sejalan dengan ekonomi Pancasila dan bersifat compatible walaupun tidak sepenuhnya substitutable. Untuk itu, ekonomi syariah menurut Edi Swasono tidak boleh direduksi hanya dengan memusatkan pada upaya membangun lembaga keuangan syariah. Akan tetapi ekonomi syariah harus dapat menangkal sistem ekonomi yang eksploitatif secara luas, yang memelihara dan menumbuhkan kesenjangan ekonomi yang membiarkan terjadinya trade off secara sistematik, yang subordinatif dan diskriminatif yang membiarkan perkembangan faham dan perilaku laisse $z$ faire (Amalia, 2008).

Mohammed Obaidullah (2013) menegaskan ekonomi syariah bukan hanya diartikan sebagai ayatisasi atau labelisasi terhadap produk ekonomi konvensional tetapi ekonomi syariah lebih bersifat substantif. Jadi mengistilahkan ekonomi syariah bukan sekedar superficial Islamic wraping. Semua produk ekonomi konvensional misalnya leasing disamakan dengan ijarah, trading dengan tijarah, insurance dengan takaful.

Said A. Meenai (1984) mendefinisikan ekonomi syariah the knowledge and application of instructions and rules of the shari'ah that prevent injustice in the acquisition and disposal of material resources in order to provide satisfaction to human beings and enable them to perfom their obligation to Allah and the society. Ekonomi syariah adalah pengetahuan yang mengaplikasikan nilai-nilai syariah pada transaksi bisnis yang terbebas dari ketidakadilan, dalam mendapatkan sumber daya material dalam memenuhi kebutuhan manusia dalam rangka melaksanakan misi hidup dan menjalankan kewajiban kepada Allah dan masyarakat (hablum min Allah dan hablum min an naas).

S.M Hasanuz Zaman (1991) memberikan definisi ekonomi syariah, Islamic Economic is the knowledge and applications and rules of the shariah that prevent injustice in the requisition and disposal of material resources in other to provide satisfaction to human being and enable them to perform they obligations to Allah and the society. Ekonomi syariah adalah pengetahuan dan aplikasi dan aturan syariah yang mencegah ketidakadilan dalam permintaan dan pembuangan sumber daya material di lain untuk memberikan kepuasan bagi manusia dan memungkinkan mereka untuk melakukan kewajiban mereka kepada Allah dan masyarakat. 
MM Metwally (1995) mendefinisikan ekonomi syariah sebagai ilmu yang mempelajari perilaku muslim dalam suatu masyarakat Islam yang mengikuti Al-Qur'an, al-Sunnah, Ijma dan Qiyas. Metwally memberikan alasan bahwa dalam ajaran Islam, perilaku individu dan masyarakat dikendalikan kearah bagaimana memenuhi kebutuhan dan menggunakan sumber daya yang ada. Dalam ajaran Islam ditegaskan bahwa sumber daya yang tersedia adalah berkecukupan dan karena itu, dengan kecakapannya, manusia dituntut untuk berupaya memakmurkan dunia dan upaya ini merupakan bentuk ibadah kepada Tuhan. Dengan demikian, Ekonomi syariah merupakan ilmu dan sistem yang bertugas untuk memanfaatkan sumber daya yang tersedia dan berkecukupan itu dalam rangka memnuhi kebutuhan masyarakat dalam konteks kemaslahatan bersama.

Masykuri Abdullah (2011) memberikan empat ciri dasar ekonomi syariah yang pertama ekonomi Islam, adalah ekonomi yang mementingkan pengakuan hak-hak milik pribadi, kedua ekonomi syariah saling membantu dan kerjasama, ketiga ekonom Islam menekankan pentingnya pemerataan pendapatan dan kekayaan, keempat ekonomi syariah adalah ekonomi yang mengharuskan adanya kejujuran.

\section{Metode Penelitian}

Penelitian ini menggunakan pendekatan kualitatif untuk menjelaskan dan menganalisis bagaimana pendekatan ekonomi syariah menjadi solusi terhadap munculnya persoalan ekonomi yang diakibatkan oleh pandemi covid-19 yang melanda dunia saat ini.

Sumber data penelitian ini adalah referensi yang terkait dengan konsep ekonomi syariah yang ditulis oleh berbagai ahli dan juga data-data yang bersumber dari media nasional. Adapun pembahasan penelitian berbentuk deskriptif. Tujuannya adalah untuk membuat deskripsi, atau gambaran, faktual dan akurat mengenai pendekatan ekonomi syariah dalam memberikan solusi terhadap persoalan ekonomi akibat pandemic covid19 (Nazir, 1998). 


\section{4 | Nurhidayat, PENDEKATAN EKONOMI SYARIAH DALAM MENYELESAIKAN MASALAH................}

\section{Pembahasan}

\section{Pendekatan Ekonomi Syariah Solusi Terhadap Masalah Kemiskinan Akibat Covid-19 \\ Kemiskinan global menurut M. Yunus disebabkan oleh dua hal. Pertama}

kemiskinan sudah menjadi ancaman bagi terwujudnya perdamaian dunia, ini terbukti bahwa di negara-negara yang berpenduduk miskin konflik dan perang sangat sulit diselesaikan. Perang masih menjadi penyelsaian akhir dari berbagai konflik. Penyebab kedua kemiskinan menjadi masalah global dikarenakan kemiskinan menjadi penghambat penegakan hak asasi manusia (Yunus, 2008).

Pendapat Yusuf Qardhawi tentang problem kemiskinan tidak lagi menjadi problem ekonomi, akan tetapi sudah menjadi problem sosial dan politik, ini menarik untuk dikaji, sebab problem ekonomi ini akan berdampak kepada problem sosial, pendidikan, kesehatan dan politik. Problem inilah yang ini dihadapai oleh negara-negara berpenduduk muslim. Sehingga hal ini dapat membahayakan dan mengancam akidah, akhlak kelogisan berfikir, keluarga dan mengancam masyarakat muslim. Yusuf Qardhawi menjelaskan bahwa keterbelakangan ekonomi selain faktor eksternal, juga disebabkan karena umat Islam belum menjalankan ajaran agama dalam berekonomi (AlQaradhawi, 2005).

Kemiskinan secara umum disebabkan oleh dua faktor yaitu faktor internal dan faktor ekternal. Faktor internal disebabkan oleh penduduk sendiri contoh rendahnya tingkat pendidikan, rendahnya ketrampilan, dan budaya. Sedangkan kemiskinan yang diakibatkan faktor eksternal antara lain rendahnya kemampuan mengakses sumberdaya ekonomi, dan diakibatkan oleh bencana termasuk wabah corona bisa menjadikan seseorang menjadi miskin.

Menurut Kamus Umum Bahasa Indonesia, secara harfiah kata miskin diberi arti tidak berharta benda. Sehingga ada tiga tipe orang miskin, yakni miskin (poor), sangat miskin (very poor) dan termiskin (poorest). Penggolongan ini berdasarkan pendapatan yang diperoleh setiap tahun. Orang miskin adalah orang yang disebabkan berpenghasilan rendah kalau diwujudkan dalam bentuk beras yakni $320 \mathrm{~kg} / \mathrm{orang} / \mathrm{tahun}$. Jumlah tersebut dianggap cukup memenuhi kebutuhan makan minimum $(1,900$ kalori/orang/hari dan $40 \mathrm{gr}$ protein/orang/hari). Orang yang sangat miskin 
berpenghasilan antara $240 \mathrm{~kg}$ sampai $320 \mathrm{~kg}$ beras/orang/tahun, dan orang yang digolongkan sebagai termiskin berpenghasilan berkisar antara $180 \mathrm{~kg}, 240 \mathrm{~kg}$ beras/orang/tahun (https://kbbi.web.id/ diakses Rabu, 1 Juli 2020).

Menurut BPS, penduduk miskin adalah mereka yang asupan kalorinya di bawah 2,100 kalori berdasarkan kategori food dan nonfood diukur menurut infrastruktur antara lain jalan raya, rumah, serta ukuran sosial berupa kesehatan dan pendidikan. Menurut ketentuan BPS kebutuhan makanan minimum per kapita penduduk yaitu sebanyak 2.100 kalori per hari. Mengingat bahan makanan penduduk berbeda-beda, maka ukuran konsumsinya dilihat dari jumlah rupiahnya.

Upaya luar biasa yang sudah dilakukan Lembaga Zakat dalam mengantisipasi penyebaran virus corona. Pertama melakukan upaya preventif kedua upaya kuratif. Upaya preventif pertama mengedukasi masyarakat akan pentingnya hidup sehat dan islami hal ini sebagaimana seruan Rasulullah dalam sebuah hadisnya "mukmin yang kuat lebih baik dan lebih dicintai oleh Allah daripada mukmin yang lemah" (HR. Muslim). Kedua menyadarkan umat akan pentingnya memutus mata rantai dengan cara berdiam diri di rumah. Inilah seruan yang disampaikan oleh Rasululah disaat menghadapi wabah penyakit yang mematikan Rasulullah mengingatkan umat Tha'un (penyakit menular) merupakan teguran dari Allah sebagai ujian untuk hamba apabila terjadi maka berdiamlah di tempat kamu berada jangan kamu lari" (HR Bukhari Muslim) (Nurhidayat, Monitor.co.id, Jumat, 24 April, 2020).

Upaya preventif kedua mengajak masyarakat untuk melakukan isolasi diri (social distance) inipun sesuai dengan seruan Rasulullah juga menganjurkan untuk isolasi bagi yang sedang sakit dengan yang sehat agar penyakit yang dialaminya tidak menular kepada yang lain. Dalam hadis disebutkan: Janganlah yang sakit disatukan dengan yang sehat (HR Bukhari dan Muslim).

Upaya kuratif yang dilakukan Lembaga Zakat adalah dengan membangun Rumah Sakit yang siap menampung pasien corona, mereka harus menyiapkan tenaga medis dan relawan yang siap melayani masyarakat yang terdampak corona. Yang kedua bantuan konsumtif sebagai upaya untuk membantu memenuhi kebutuhan masyarakat miskin 


\section{6 | Nurhidayat, PENDEKATAN EKONOMI SYARIAH DALAM MENYELESAIKAN MASALAH.}

yang terdampak virus corona. Apalagi jika diberlakukan lockdown lembaga zakat menjadi garda terdepan dalam melayani masyarakat.

Zakat sebagai ibadah maliyah merupakan kewajiban yang dibebankan kepada orang atau korporasi yang memiliki kelebihan harta (nishab), jadi bagi kalangan masyarakat yang memiliki surplus ekonomi atau muzaki mereka diwajibkan untuk diambil zakatnya. Lihat surat at taubah 103 Ambillah zakat dari harta mereka, guna membersihkan dan menyucikan mereka, dan berdoalah untuk mereka. Sesungguhnya doamu itu (menumbuhkan) ketenteraman jiwa bagi mereka. Allah Maha Mendengar, Maha Mengetahui.

Untuk siapa zakat ini diberikan kepada mereka yang memiliki defisit ekonomi mustahik. Hal ini dijelaskan dalam surat at taubah ayat 60 sesungguhnya zakat itu untuk fakir, miskin, amil, muallaf, riqab, debitur, profesi dakwah, ibn sabil. Jadi zakat ini merupakan solusi terhadap persoalan ekonomi. Sesungguhnya zakat-zakat itu, hanyalah untuk orang-orang fakir, orang-orang miskin, pengurus-pengurus zakat, para mu'allaf yang dibujuk hatinya, untuk (memerdekakan) budak, orang-orang yang berhutang, untuk jalan Allah dan untuk mereka yuang sedang dalam perjalanan, sebagai suatu ketetapan yang diwajibkan Allah, dan Allah Maha Mengetahui lagi Maha Bijaksana.

Secara filosofis, zakat memiliki beberapa makna an-nama' (pertumbuhan) artinya menumbuhkan harta, kepedulian sosial, ukhuwah kaya dan miskin, sesuai pertumbuhan zaman. Al-Barokah (Keberkahan) memberkahkan harta, kehidupan masyarakat, dan mengundang keberkahan Allah. Az-Ziyadah (Tambahan/Kelebihan) dikeluarkan setelah mencapai nishab, kelebihan dari kebutuhan. As-Sholah (Baik) berdampak baik bagi Muzakki dan mustahik, mengurangi kesenjangan sosial, sebagai perilaku yang terpuji, mendatangkan kebaikan dunia dan akhirat. Ath-Thoharoh (Suci) membersihkan harta dari hak orang lain, hati dari penyakit kikir dan rakus, hati orang miskin dari benci, hasad dan dendam terhadap orang kaya, sumber dana zakat harus penghasilan yang halal (Al-Qardhawi, 2005).

Zakat memiliki beberapa fungsi antara lain fungsi Ibadah (Keta'atan dan Syukur). Fungsi Sosial (Ukhuwah dan Keseimbangan). Fungsi Ekonomi (Pemerataan dan Pemberdayaan) Fungsi Pembentukan Karakter dan Mental (Dermawan, Ikhlas, Peduli, 
Disiplin, Tidak Cinta Dunia, Mulia). Zakat membentengi akidah umat dari masalah ekonomi. Karena itu Zakat ini jaminan penghidupan. Zakat bukan hanya sekali tapi diambil secara berulang-ulang setiap tahun begitu juga zakat ftrah setiap tahun. Secara konseptual zakat memang dapat membantu mustahik untuk meningkatkan konsumsi dan produksi yang secara agregat berkontribusi meingkatkan pertumbuhan ekonomi khususnya di era pandemi.

Dalam konteks sejarah sejak masa Rasulullah, dan khulafaur rasyidin, zakat dihimpun melalui lembaga, sehingga zakat memiliki multiplier effect. Yang kedua zakat tidak hanya konsumtif tetapi produktif. Pada saat pandemi covid-19 zakat harus responsif dalam memenuhi kebutuhan mustahik. Banyak mustahik baru akibat wabah ini, mereka yang di PHK butuh pekerjaan. Ini adalah mustahik alamiah. Zakat tidak memenuhi kebutuhan sesaat tetapi mempunyai pengaruh besar terhadap kehidupan masyarakat. Melalui pemberdayaan kemiskinan didibuatkan lapangan pekerjaan.

Pada zaman Umar bin Abdul Aziz dalam tempo 30 bulan tidak ditemukan lagi masyarakat miskin, karena semua muzakki mengeluarkan zakat dan distribusi zakat tidak sebatas konsumtif, tetapi juga produktif. Peran zakat sangat penting dan strategis. Fakta sejarah membuktikan di zaman sahabat, ummayah, dan Abbasiah, ekonomi umat tumbuh karena potensi zakat umat digali secara optimal.

Inilah kelebihan dari zakat yang kelola secara profesional melalui lembaga amil zakat. Sehingga dengan manajemen modern zakat memiliki frekuensi yang besar dalam menuntaskan problematika ekonomi. Dengan zakat produktif zakat mempunyai multiplier effect. Surat Rum 39 menjelaskan makna implisit dari multiplier effect ini. Walau secara zahirnnya zakat itu berkurang, tetapi hakikatnya menjadi sebab bangkitnya ekonomi negara.

Dalam pandangan Arramli Assyafii zakat menolak bahaya ekonomi yang diakibatkan oleh berbagai bencana. Oleh karenanya Lembaga Zakat dapat mengalokasikannya untuk pembelian alat-alat medis, atau alat kesehatan, dan menolong korban PHK Namun demikian, karena jumlah dana yang dihimpun Lembaga zakat tidak seimbang dengan jumlah mustahik. Maka lembaga zakatpun membutuhkan langkahlangkah strategis dan taktis yang dapat dilakukan antara lain merelokasi anggaran dan

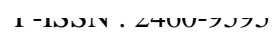

DOI. 10.36908/isbank 


\section{Nurhidayat, PENDEKATAN EKONOMI SYARIAH DALAM MENYELESAIKAN MASALAH.}

melakukan efisiensi. Dalam kondisi yang mendesak seperti ini sehingga menurut Ibnu Hazm jika jika lembaga zakat tidak mampu mengatasi persoalan ekonomi akibat pandemi ini ini maka negara dapat memaksa aghniya untuk menanggung mereka.

Solusi jangka pendek lembaga zakat dalam situasi ini adalah terus melakukan edukasi kepada masyarakat akan pentingnya membayar zakat di tengah situasi meningkatnya jumlah mustahik, kedua lembaga zakat harus melakukan strategi penghimpunan melalui strategi digitalisasi fundraising, dan yang ketiga lembaga zakat harus membuat skala perioritas saat ini dengan mengalokasikan dan memprioritaskan zakat konsumtif. Dengan seperti itu maka geliat ekonomi Ramadhan tahun ini masih tetap dirasakan oleh umat Islam dan banga Indonesia secara umum karena ekonomi Ramadhan ini dirasakan oleh siapapun.

\section{Pendekatan Ekonomi Syariah Solusi Munculnya Penimbunan Barang (ihtikar)}

Terhadap masalah ini para ekonom muslim seperti Yahya bin Umar sangat mengecam perilaku menimbun barang (ihtikar), apapun alasanya. Karena berdasarkan padangan Yahya bin Umar penimbunan barang (ihtikar) ini adalah kejahatan yang akan menyebabkan kesengsaraan rakyat. Penimbunan barang akan menimbulkan kelangkaan barang yang akan berakibat kenaikan harga. Jika hal itu dilakukan meurutnya, maka barang hasil kejahatan itu harus dilelang dan keuntunganya disedekahkan, dengan ketentuan modal pokoknya dikembalikan kepada pelaku. Pemerintah harus memberikan peringatan kepada pelaku ihtikar sebagai efek jera bagi si pelaku. Apabila mereka msih mengulanginya maka pemerintah harus mengambil tindakan sesuai dengan hukum yang berlaku. Pandangan Yahya bin Umar ini sangat beralasan karena penimbunan barang ini bisa berdampak kepada kelangkaan barang dan inflasi (Chaudhary, 2012).

Jika terjadi kelangka barang dan inflasi menurut Al-Ghazali akan mengakibatkan terjadinya azab dalam perekonomian. Al-Ghazali mengutip ayat Al-quran "Dan orangorang yang menimbun harta-harta mereka berupa emas dan perak dan tidak menginfakanya di jalan Allah, maka berikanlah kabar kepada mereka tentang azab yang pedih. (QS. At-taubah [9]: 34. Azab dalam perekonomian mengakibatkan terjadinya ketimpangan, dan meningkatnya kemiskinan. Oleh karena itu Al-Ghazali di dalam 
Adabul Kasbi wal-maasy menekankan penting ilmu ekonomi para pebisnis. Dengan pemahaman yang dimiliki pebisnis dalam bisnisnya tidak akan melakukan ihtikar (Haq, 1996).

Pada saat terjadi pandemi virus covid-19 ini kalau ada oknum pengusaha yang memanfaatkan situasi ini dengan menimbun barang terutama kebutuhan pokok seperti masker. Maka menurut Yahya bin Umar dan Al-Ghazali adalah kejahatan yang akan mengakibatkan kesengsaraan bagi rakyat. Oleh karenanya harus dihukum. Pendapat kedua ekonom muslim tersebut sejalan dengan ketentuan hukum di Indonesia yakni Undang-undang Nomor 7 Tahun 2014 tentang perdagangan pada pasal 29 dijelaskan pelaku usaha dilarang menyimpan barang kebutuhan pokok dan/atau barang penting dalam jumlah dan waktu tertentu pada saat terjadi kelangkaan barang, gejolak harga dan atau hambatan lalu lintas perdagangan barang. Pelaku usaha dapat melakukan penyimpanan barang kebutuhan pokok dan/atau barang penting dalam jumlah dan waktu tertentu jika digunakan sebagai bahan baku atau bahan penolong dalam proses produksi atau sebagai persediaan barang untuk didistribusikan (Chapra, t.t).

Barang kebutuhan pokok yang dimaksud adalah barang yang menyangkut hajat hidup orang banyak dengan skala pemenuhan kebutuhan yang tinggi serta menjadi faktor pendukung kesejahteraan masyarakat, seperti beras, gula, minyak goreng, mentega, daging sapi, daging ayam, telur ayam, susu, jagung, kedelai, dan garam beryodium. Kedudukan masker sama pentingnya dengan sembako disaat terjadinya pandemic virus covid-19.

\section{Pendekatan Ekonomi Syariah Solusi Munculnya Masalah Kelangkaan Barang}

Yahya bin Umar dalam kitab al-ahkam al-suq memberikan penegasan eksistensi harga sangat penting dalam transaksi bisnis sehingga pengabaian atasnya akan menimbulkan kerusakan dalam masyarakat. Oleh sebab itu menurutnya penetapan harga atau al-tas'ir tidak boleh dilakukan. Hal ini berdasarkan hadis dari Anas bin Malik Rasulullah bersabda telah melonjak harga di pasar pada masa Rasulullah mereka para sahabat berkata Wahai Rasulullah tetapkanlah harga bagi kami, Rasulullah menjawab sesungguhnya Allah-lah yang menguasai (harga) yang memberi rizki, yang 


\section{0 | Nurhidayat, PENDEKATAN EKONOMI SYARIAH DALAM MENYELESAIKAN MASALAH................}

memudahkan dan yang menetapkan harga. Aku sungguh berharap bertemu dengan Allah dan tidak seorang pu (boleh) memintaku untuk melakukan suatu kezaliman dalam persoalan jiwa dan harta (HR Abu Dawud) (Mannan, 1984).

Yahya bin Umar berargumen bahwa pemerintah bagaimana tidak boleh melakukan intervensi pasar kecuali dalam dua hal. Pertama para pedagang tidak menjual barang yang sangat dibutuhkan masyarakat contoh sembako atau alat kesehatan seperti masker, hand sanitizer yang sangat dibutuhkan saat ini sehingga kondisi ini akan menimbulkan kelangkaan yang berdampak kenaikan harga maka pemerintah boleh intervensi pasar. Kedua para pedagang banyak melakukan banting harga (siyasah al-ighraq), praktek dumping akan menimbulkan persaingan yang tidak sehat dan dapat menimbulkan instabilitas ekonomi. Intervensi pemerintah terhadap harga ini pernah dilakukan oleh Pemerintah Umar bin Khattab, ketika ada pedagang kismis yang melakukan dumping maka khalifah menawarkan dua opsi menaikan harga sesuai standar atau pergi dari pasar (Al-Qardhawi, 2001).

Ibnu Taimiyah memiliki pandangan mengenai pasar bebas menurutnya naik turunya harga tidak selalu berkaitan dengan kezhaliman yang dilakukan oleh seseorang. Akan tetapi bisa disebabkan oleh kekurangan produksi atau menurunnya barang impor. Kelimpahan dan kelangkaan tidak selamanya diakibatkan oleh perbuatan manusia, tetapi bisa diakibatkan keadilan dan juga ketidakadilan. Dalam kitab Majmu' Fatawa Ibnu Taimiyah mengemukakan beberapa faktor pengaruh fluktuasi permintaan yang mempengaruhi harga, antara lain faktor kebutuhan manusia yang beraga dan bervariasi, pada saat terjadi kelangkaan yang diakibatkan oleh bencana maka barang akan sangat dibutuhkan dibanding ketika barang melimpah dan inilah yang akan memicu inflasi (Haneef, 2011).

\section{Pendekatan Ekonomi Syariah Solusi Munculnya Masalah Inflasi}

Harga yang adil menurut Ibnu Taimiyah adalah nilai harga dimana para pedagang menjual barang daganganya dan diterima secara umum sebagai hal yang sepadan dengan barang yang dijualataupun barang yang sejenis lainya di tempat dan waktu tertentu. 
Imam Al-Maqrizi menyatakan bahwa inflasi ini merupakan fenomena alam yang menimpa kehidupan manusia di seluruh dunia sejak dulu, sekarang dan akan datang. Menurutnya inflasi terjadi ketika harga-harga secara umum mengalami kenaikan dan berlangsung secara terus menerus. Pada saat inflasi tersebut ketersediaan barang mengalami kelangkaan. Inflasi ini menurut Al-Maqrizi secara umum disebabkan oleh dua faktor yaitu faktor alamiah dan human error.

Inflasi alamiah ini diakibatkan oleh bencana alam dan bencana akibat penyakit menular yang diakibatkan oleh virus berbahaya. Faktor penyebab ini menurut AlMaqrizi tidak bisa dihindari oleh manusia. Dampak dari bencana tersebut akan mengakibatkan kepanikan besar karena manusia mengalami berbagai kesulitan ekonomi. Bahan makanan pokok akan mengalami kelangkaan secara drastis, sementara permintaan makin meningkat. Sementara daya beli masyarakat mengalmi penurunan. Akibatnya menurut Al-Maqrizi transaksi ekonomi mengalami kemacetan bahkan bisa terhenti, inilah yang dialami saat ini akbat isolasi diri, social distancing atau physical distancing, perekonomian bisa terhenti. Lihat ekonomi Italia, China dan Indonesia yang mengalami penurunan (Al-Qardhawi, 2001).

Dalam pandangan Al-Maqrizi masalah ini bisa menimbulkan instabilitas, sebab dalam krisis ekonomi rakyat akan menutut pemerintah, sementara pemerintahpun mengalami defisit anggaran sementara satu sisi harus mengeluarkan dana yang besar untuk mengahadapi bencana yang terjadi. Kalau kondisi ini tidak mampu diselesaikan oleh pemerintah menurut Al-Maqrizi instabilitas ekonomiini akan menimbulkan instabilitas sosial dan politik sehingga bisa menyebabkan runtuhnya pemerintahan (Chapra, 2014). 


\section{Simpulan}

Penelitian ini bertujuan untuk memberikan gambaran dan menganalisis bagaimana pendekatan ekonomi syariah dalam menjawab persoalan ekonomi akibat pandemi covid-19. Melalui pendekatan ekonomi syariah ini apakah persoalan ekonomi dapat teratasi. Penelitian ini berkesimpulan bahwa ekonomi syariah secara konseptual memang menjadi solusi terhadap persoalan ekonomi akibat covid-19. Sebab pendekatan ekonomi syariah dikonseptualisasikan dan memiliki orientasi sebagai problem solving dari berbagai persoalan ekonomi yang bisa muncul kapan saja dan di dunia manapun.

\section{DAFTAR PUSTAKA}

Abdillah, Masykuri. (2011). Islam dan Dinamika Sosial Politik di Indonesia. Jakarta: PT. Gramedia Pustaka Utama.

Al-Qardhawi, Yusuf, (2001). Peran Nilai dan Moral dalam Perekonomian Islam, terjemahan : Daurul Qiyam wal Akhlaq fil Iqtishodil Islami, Jakarta : Robbani Press, 2001

Al-Qardhawi, Yusuf. (2005). Spektrum Zakat Dalam Membangun Ekonomi Kerakyatan. Jakarta : Zikrul Hakim.

Amalia, Euis. (2008). Kadilan Distributif Dalam Ekonomi Syariah: Penguatan Peran LKM Dan UKM Di Indoensia. Jakarta: Rajagrafindo.

BPS.go.id, diakses 20 April 2020.

Chapra, M. Umer, The Islamic Vision of Development in Light of the Maqasid alShari'ah. London and Washington: IIIT

Chapra, Umer, (2014). The Future of Economics an Islamic Perspektive, Islmic Foundation.

Haneef, Mohamed Aslam, dan Hafas Furqani. (2011). Methodology of Islamic Economic: Overview of Present State and Future Direction. IIUM Journal of Economics and Management, Vol.19 2011.

Haq, Ul Irfan. (1996). Economic Doktrines of Islam: A Study in the Doctrines of Islam and Their Implications for Poverty, Employment and Economic Growth. Interational Institute of Islamic Thought Herndon, Virginia U.S.A.

Hasanuz Zaman S.M. (1991). Economic Function of an Islamic State, Journal of King Abdulaziz University-Islamic Economics.

https://kbbi.web.id/ diakses Rabu, 1 Juli 2020 
ISLAMIC BANKING: Jurnal Pemikiran dan Pengembangan Perbankan Syariah, Volume 6 Nomor 1 Edisi Agustus 2020

Manan, M. Abdul. (1984) Islamic Economics; Theory and Practice, Delhi.Sh. M. Ashraf, 1070. Lihat juga M. A Manan, The Making of an Islamic Economic Society, Cairo.

Mannan, Abdul, Muhammad, (1984). The Making of Islamic Economic Society: Islamic Dimensions in Economic Anallysis, Turky: International Assosiation of Islamic Bank, and International Institute for Islamic Banking and Economic. 1984

Meenai, A. Said. (1984). The Islamic Bank : A Case Study of Islam Cooperation. New York: Kegan Paul International.

Metwally, MM. (1995). Teori Dan Model Ekonomi Syariah. Jakarta: Bangkit Daya Insana.

Muhammad Sharif, Chaudhary. (2012). Fundamental of Islamic Economic System (terj) Sistem Ekonomi Islam Prinsip Dasar, Jakarta : Prenada Media Group.

Naqvi Syed Nawab Haider. (1985). Etika dan Ilmu Ekonomi: Suatu Sintesis Islami. Bandung: Mizan.

Nazir. Moh. (1998), Metode Penelitian. Jakarta : Ghalia Indonesia.

Nurhidayat, (2020), Dampak Corona Terhadap Kemiskinan Dan Cara Dompet Dhuafa Mengatasinya, Carapandang.com, 29 March 2020

Nurhidayat, Ekonomi Ramadhan Ditengah Wabah Covid-19. Monitor.co.id, Jumat, 24 April, 2020

Obaiullah, Mohammed, (2013). Financial Contracting in Currency Markets: An Islamic Evaluation. Kuala Lumpur: International Journal of Islamic Financial Services.

Rahardjo M. Dawam. (1999). Islam dan Transformasi Sosial Ekonomi, Jakarta: LSAF.

Republika.co.id, Bagaimana Ekonomi Global Terdampak Wabah Corona?, Senin 02 Mar 2020

Republika.co.id, Bank Dunia Turunkan Proyeksi Pertumbuhan Ekonomi RI 2019, Rabu 11 Desember 2019

Republika.co.id, Kerugian Global Akibat Covid-19 Capai 8,8 Triliun Dolar AS, Senin 18 May 2020

Republika.co.id., Dampak Corona, Pemerintah: Kemiskinan Bisa Naik Tajam, Selasa 14 Apr 2020

Siddiqi, N. Muhammad. (1981). Muslim Economic Thinking: A Survey of Contemporary Literature, Jeddah and The Islamic Foundation.

Yunus, Muhammad, (2008). Grameen Bank and the Nobel Peace Prize: What Political Science Can Contribute to and Learn from the Study of Microcredit, Oksan Bayulgen International Studies Review, Vol. 10, No. 3 
34 | Nurhidayat, PENDEKATAN EKONOMI SYARIAH DALAM MENYELESAIKAN MASALAH................ 